\title{
La Bioeconomía como posible estrategia comparativa. Alianza del Pacífico: caso Colombia
}

\author{
Bioeconomics as a Possible Comparative Strategy. \\ Pacific Alliance: the Case of Colombia \\ A Bioeconomia como possível estratégia comparativa. \\ Aliança do Pacífico: caso Colômbia \\ Dustin Tahisin Gómez Rodríguez \\ Universidad Uniagustiniana, Colombia. \\ E-mail: \\ dustin.gomez@uniagustiniana.edu.co \\ Héctor Mauricio Rincón Moreno \\ Universidad Uniagustiniana, Colombia. \\ E-mail: \\ dirinvestigaciones@uniagustiniana.edu.co
}

Fecha de recepción: 28/11/2017 Fecha de aceptación: 24/06/2018

Palabras clave

- Bioeconomía

- Economía ecológica

- Innovación

- Valor compartido

- Ventajas comparativas

\section{Resumen}

El objetivo del presente artículo reflexivo es analizar las posibles ventajas comparativas que posee el Estado colombiano desde el enfoque de la Bioeconomía. La metodología es de corte cualitativo y el método es de revisión documental por medio de matrices. La principal conclusión es que la Bioeconomía, tomada desde las concepciones de la Nueva economía, es una propuesta desde el contexto colombiano viable para ser tenida en cuenta como ventaja comparativa frente a los miembros de la Alianza del Pacífico. En efecto, el territorio colombiano posee una riqueza biológica que puede ser utilizada para enriquecer el portafolio económico del país en un mundo que tiende a ser globalizado.
Abstract
The objective of this reflective article is to analyze the possible comparative advantages that the Colombian State has from the Bioeconomy approach. The methodology is qualitative and the method is documentary review through matrices. The main conclusion is that the Bioeconomy, taken from the conceptions of the New Economy, is a proposal from the viable Colom- bian context to be taken into account as a comparative advantage against the members of the Pacific Alliance. In effect, the Colombian territory has a biological wealth that can be used to enrich the country's economic port- folio in a world that tends to be globalized.

Keywords

- Bioeconomics

- Ecological economics

- Innovation

- Shared value

- Comparative advantages 
Palavras-chave

- Bioeconomia

- Economia ecológica

- Inovação

- Valor compartilhado

- Vantagens comparativas

\section{Resumo}

0 objetivo deste artigo reflexivo é analisar as possíveis vantagens comparativas que 0 Estado colombiano tem da abordagem da Bioeconomia. A metodologia é qualitativa e 0 método é uma revisão documental por meio de matrizes. A principal conclusão é que a Bioeconomia, tirada das concepções da Nova Economia, é uma proposta do contexto viável colombiano a ser levada em conta como uma vantagem comparativa contra os membros da Aliança do Pacífico. Com efeito, o território colombiano tem uma riqueza biológica que pode ser usada para enriquecer o portfólio econômico do país em um mundo que tende a ser globalizado. 